\title{
1. The United States of America
}

\author{
A comparativist critique of US judicial \\ review of fundamental rights cases: \\ exceptionalisms, paradoxes and \\ contradictions
}

Michel Rosenfeld

\subsection{INTRODUCTION}

US constitutional adjudication is exceptional and in certain ways paradoxical. American judicial exceptionalism is widely recognized and mainly linked to the US Supreme Court's (USSCt) unique challenge posed by the need to interpret an eighteenth century bill of rights for a contemporary society; the controversy over originalism; the tendency to convert all important divisive political issues into constitutional ones; and the enormous powers of the USSCt in fashioning and shaping fundamental rights aided by the extreme rigidity of the US Constitution's amendment provision. ${ }^{1}$ The paradoxes surrounding US constitutional adjudication, on the other hand, do not as readily come to the fore. These paradoxes are nonetheless numerous, and to cite but one, include the politicization of constitutional law as an inextricable consequence of the systematic constitutionalization of divisive political issues. ${ }^{2}$ To better appreciate this latter paradox, it is useful to draw a brief comparison between the USSCt and specialized civil law constitutional adjudicatory bodies, such as the German Constitutional Court (GCC) and the French Constitutional Council (FCC). For over 200 years, the US Constitution has been treated as law and constitutional rights as legal rights. ${ }^{3}$ In

See US Constitution 1787, art V.

2 See below 1.2.2 Key extrinsic factors bearing on the distinctiveness of US constitutional adjudication.

3 See Marbury v Madison 5 US 137 (1803). 
comparison, the GCC applies constitutional standards to private party transactions, ${ }^{4}$ thus directly entering the realm traditionally left to legislative policymaking: ${ }^{5}$ and the FCC was squarely set up as a political body. ${ }^{6}$ Accordingly, the USSCt would seem much less political than its two European counterparts, both in terms of its institutional setting and of its adjudicative mission. Nevertheless, within the past several decades, the USSCt has had greater legitimacy problems for being overly political than either the GCC or the FCC. ${ }^{7}$ More generally, as will become apparent in the course of the analysis below, both American exceptionalism and the paradoxes associated to it are complex, multifaceted and overdetermined.

To better appreciate the exceptionalism and paradoxes involved, US constitutional adjudication must be placed in the context of the legal tradition from which it emerges and understood in relation to the particular conception of fundamental rights that is predominant in the US. Accordingly, the first part of this chapter lays out the institutional context in which USSCt constitutional adjudication is embedded. The second part outlines the American conception of rights and the US Constitution's basic scheme for the protection for fundamental rights. Finally, the third part concentrates on some of the most controversial USSCt decisions in fundamental rights cases, including some of the most recent ones, with special emphasis on institutional implications and on conflicts among proponents of more expansive views of rights and those of more restrictive views. Ultimately, as we shall see, both US exceptionalism and the paradoxes it generates are based on a combination of institutional and contextual factors as well as on a series of dichotomies and contradictions. Given all this, one might expect a great deal of disillusion regarding the predicament of US constitutional adjudication.

4 Jörg Fedtke, 'Drittwirkung in Germany' in Jörg Fedtke and Dawn Oliver (eds), Human Rights and the Private Sphere: A Comparative Study (Routledge 2007) 144.

5 This is done through deployment of the 'third party effect' or Drittwirkung. See Norman Dorsen et al., Comparative Constitutionalism: Cases and Materials (Thomson/West, 2nd edn, 2010) 896. See also Bernhard Schlink, 'German Constitutional Culture in Transition' in Michel Rosenfeld (ed.), Constitutionalism, Identity, Difference and Legitimacy: Theoretical Perspectives (Duke University Press 1994) 197 (criticizing GCC for engaging in policymaking). 48.

6 Alec Stone Sweet, The Birth of Judicial Politics in France (OUP 1992)

7 Michel Rosenfeld, 'Constitutional Adjudication in Europe and the United States: Paradoxes and Contrasts' (2004) 2 Intl J Cons L 633, 652 (nothing equivalent in France or Germany to the US 'countermajoritarian' difficulty). 
Surprisingly, for the most part, it is not American exceptionalism as such or the paradoxes it fosters in and of themselves that bear the brunt of discontent. Instead, as will become apparent in the course of the following analysis, most frustrations and criticisms come from within antagonistic positions within exceptionalism - for example, originalists versus adaptionists - and within the contrasting poles giving rise to the contradictions and dichotomies that shape the actual paradoxes at play.

\subsection{US CONSTITUTIONAL ADJUDICATION IN ITS INSTITUTIONAL AND HISTORICAL CONTEXT}

For both intrinsic and extrinsic reasons, the USSCt differs in significant respects from highest courts engaging in constitutional adjudication in both civil law and common law countries. The intrinsic reasons in question stem from differences in constitutional design and from contrasts in legal approach and judicial culture. The extrinsic reasons are, for their part, contextual in nature as they relate primarily to issues arising in the ongoing relationship between constitutional adjudication and political as well as societal factors, that relationship being mediated by the dynamic imprints of the relevant polity's constitutional identity. ${ }^{8}$

\subsubsection{Intrinsic Reasons for the Distinctiveness of US Constitutional Adjudication}

Four principal features of constitutional design set the USSCt apart from other constitutional adjudicatory institutions. Moreover, the differences at stake are most obvious in comparison to constitutional courts in civil law countries, but they are also important in comparison to supreme or high courts in other common law countries. The four features involved include: the US Constitution's separation of powers provisions that make the federal judiciary one of the three separate and coequal branches of the US Government, the other two being the legislative branch entrusted to the US Congress and the executive branch headed by the US President; ${ }^{9}$ the limitation of the powers of the federal judiciary to the adjudication of 'cases or controversies', ${ }^{10}$ thereby precluding ex ante or

8 See generally, Michel Rosenfeld, The Identity of the Constitutional Subject: Selfhood, Citizenship, Culture and Community (Routledge 2010).

9 See US Constitution 1787, arts I, II, and III.

10 Ibid., art III, s 2, cl 1. 
abstract review ${ }^{11}$ as well as advisory opinions; ${ }^{12}$ the rigidity of the constitutional amendment provision, ${ }^{13}$ thus effectively precluding adoption of any proposed amendment that does not command virtual consensus resulting in a lack of significant political opposition; and the particular constitutional formulation of the fundamental rights to which it affords protection and which are for the most part specified in the US Constitution's Bill of Rights and Fourteenth Amendment.

Not only is the US the paramount model for decentralized constitutional review as nearly every state and federal court throughout the country is empowered to adjudicate constitutional rights claims, but it also stands out by virtue of its embedding judicial review within a 'checks and balances' framework. The federal judiciary headed by the USSCt is thus an independent and coequal branch of the federal government that is meant to check and counterbalance the powers of the US President and those of the legislative branch comprised of the US House of Representatives and the US Senate. Moreover, the overall scheme of 'checks and balances' put forth by the US Constitution is one designed to foster competition among several distinct units of democracy in order to minimize what the country's founders perceived as a particularly pernicious evil of unrestrained democratic government, namely 'the tyranny of the majority'. ${ }^{14}$ The constitutionally set divisions among units of democracy within the US operate both vertically and horizontally: vertically, through American federalism, each of the country's 50 states constitutes a unit of democracy with its own executive, legislative and judicial branch; ${ }^{15}$ and horizontally, through the accountability to different electorates respectively, by the US President, the US House of Representatives, and the US Senate, ${ }^{16}$ and even indirectly the

11 Wojciech Sadurski, 'Constitutional Review in Europe and in the United States: Influences, Paradoxes, and Convergence' (2011) Sydney Law Research Paper 11/15, $10<\mathrm{http}: / /$ ssrn.com/abstract=1754209> accessed 31 March 2015.

12 Ibid., 11.

13 Ibid., 17.

14 See James Madison, The Federalist Papers (1788) N 10.

15 See US Constitution 1787, art IV, cl 4 ('The United States shall guarantee to every State in this Union a Republican form of government ...').

16 The President is elected upon obtaining a majority in the Electoral College which depends on voting in each individual state and upon according each state a number of electors in the Electoral College based on that state's population. To become a Senator, a candidate must win a statewide election whereas to become a Representative in the US House of Representatives, a candidate must win a district wide election within a state. Thus, for example, if a state is in part urban and in part rural, a Senator would be accountable to both 
USSCt to the extent that the President nominates and the Senate confirms USSCt justices by majority vote. As federal judges are appointed for life, however, the federal judiciary ultimately provides an antimajoritarian check on its coequal branches of the federal government whenever they decide that a federally enacted law or an executive order or decree is unconstitutional. At the same time, the federal judiciary also administers an antimajoritarian check upon individual state majorities whenever it strikes down a state law that it adjudges incompatible with the US Constitution.

Because the US Constitution is very difficult to amend - to be adopted, an amendment must garner a two-thirds vote in each of the two houses of the US Congress plus a positive vote in three-quarters of the state legislatures ${ }^{17}$ - the combination of the first and the third of the four constitutional features listed above sets USSCt constitutional adjudication as an 'unchecked check' on all majoritarian units encompassed within the US constitutional design. ${ }^{18}$ This, in turn, gives rise to the 'countermajoritarian difficulty', which, if left uncontained and unmitigated, arguably would risk transforming the basic commitment to democracy and majoritarianism inscribed in the US Constitution with few textually based antimajoritarian exceptions ${ }^{19}$ - albeit in the context of a plurality of majoritarian political and institutional units - into a judicial dictatorship. ${ }^{20}$ In as much as USSCt decisions on constitutional fundamental rights questions can only be overruled by the USSCt itself, but remain, as a matter of fact, beyond repeal or modification by any other institution or

these constituencies whereas a Representative with an urban or a rural district would only be accountable to one of the two.

17 As one state is unicameral and the others are bicameral, there are 99 state legislative bodies. Accordingly, a negative vote by 13 of the 99 state legislative bodies on a proposed amendment would be sufficient to assure its defeat.

18 In contrast to the USSCt's constitutional adjudications which are pretty much de facto immune from review or overturning by any other governmental institution or electoral process, that court's decisions in cases that do not involve the US Constitution do not amount to an unchecked check. Thus, for example, the US Congress enacted the Civil Rights Act of 1991 in part to overcome USSCt's statutory interpretations with which it disagreed. See Civil Rights Act 1991, Pub L No 102-166, paras 2(2), 3(3) (explicitly repudiating the USSCt's interpretation in Wards Cove Packing Co, Inc v Atonio 490 US 642 (1989)).

19 The principal such antimajoritarian constitutional prescriptions emanate from the Bill of Rights, which is made up of the first ten amendments to the 1787 Constitution and was adopted in 1791.

20 See, for example, Robert H Bork, The Tempting of America: The Political Seduction of the Law (Free Press 1990). 
democratic process within the US, the power of US judges is unlike that of other major constitutional democracies. Indeed, in Canada, constitutional adjudication does not give rise to any 'unchecked check' as most Supreme Court fundamental rights constitutional decisions are subject to a legislative override. ${ }^{21}$ Similarly, although clearly established as the authoritative interpreters of their respective constitutions, neither the GCC nor the FCC has the final word to the extent that the USSCt does, as the French and German Constitutions are much more easily amended than their US counterpart. 22

The 'countermajoritarian difficulty' and the 'unchecked checker' problem issuing from the exercise of USSCt constitutional review powers may seem to be significantly compensated by the limitations on the powers of the federal judiciary contained in the second of the four features of constitutional design mentioned above. These limitations revolve principally around the 'case or controversy' requirement ${ }^{23}$ whereby federal courts cannot choose the constitutional issues they address, but must depend on the generation of legal proceedings by parties who can appeal to a legally cognizable 'injury in fact' caused by application of an unconstitutional law or some other unconstitutional official conduct. ${ }^{24}$ The 'case or controversy' requirement precludes ex ante or abstract review as well the issuance of advisory opinions. ${ }^{25}$ Arguably, these limitations added to the above mentioned firm commitment to treat the US Constitution as law makes constitutional adjudication much like statutory or private law common law adjudication and thus clearly distinguishable from the clearly political ex ante abstract review such as that practiced by the FCC, often based on a demand by 60 members of Parliament who had voted against a law just adopted by a majority of that body's members. ${ }^{26}$ In the latter case, the constitutional adjudicator seems directly thrust into the political fray and is unconstrained by any concrete facts; in the case of the US, in contrast, the judge has to address the particular facts before her and apply the law of

21 See Canada Constitution Act 1982, s 33.

22 See Rosenfeld, 'Constitutional Adjudication in Europe and the United States' (n 7) 654-65, n 80. Germany does have unamendable constitutional provisions, but otherwise the German Basic Law is easier to amend than the US Constitution. See German Basic Law 1949, art 79.

23 US Constitution 1787, art III, s 2.

24 See Lujan v Defenders of Wildlife 504 US 555 (1992).

25 Sadurski (n 11).

26 George A Bermann and Etienne Picard, Introduction to French Law (Kluwer Law International 2008) 31-2. 
the constitution as she would any other law to provide a judicial resolution to the case before her. In short, by confining constitutional adjudication to judicial application of a particular body of law to particular facts, the US Constitution is presumably designed to prevent over politicization of constitutional review, thus affording plausible means of confining the USSCt 'countermajoritarian' and 'unchecked checker' problems within reasonably manageable fairly narrow bounds. ${ }^{27}$

Upon further consideration, however, the 'case or controversy' requirement has not constrained the USSCt sufficiently to satisfactorily manage, let alone overcome, the 'countermajoritarian' and 'unchecked checkers' problems. The reasons for this may be multiple and complex, but two factors stand out. The first of these involves a blunting of the particularizing and concretizing meant to be secured by the 'case or controversy' requirement; the second, revolves around the common law grounded practice of judicial interpretation which has traditionally given judges broad lawmaking powers in constructing and developing common law legal doctrines and norms as well great interpretive latitude in dealing with statutes.

Unlike all other federal courts which lack much choice in the cases or controversies which they must adjudicate, the USSCt has had virtually complete freedom since $1988^{28}$ to choose a handful among the thousands of petitions for review submitted to it every year. In recent times, the USSCt has accepted in the order of 75 out of 10000 yearly petitions. ${ }^{29}$ In view of this, the USSCt is pretty much free to choose which constitutional cases and issues it wishes to adjudicate and this undermines the analogy to the common law judge who has no choice, but to adjudicate the tort or contract dispute that an aggrieved private party decides to

27 Strictly speaking, to the extent that judicial review of the constitution can be cast as a distinct legal, as opposed to a political, function - for example, the First Amendment to the US Constitution protects the 'free exercise of religion' and therefore a judge would have to find, as a matter of straightforward legal interpretation, a law authorizing Christian prayer and penalizing Muslim prayer to have been unconstitutionally applied to a Muslim who sues to invalidate a fine imposed on him for having uttered a prayer according to the dictates of Islam USSCt constitutional adjudication would be 'checked' by the Constitution itself aided by generally accepted canons of professional judicial conduct.

28 See Supreme Court Case Selections Act 1988, 28 USC para. 1257 (enacted 27 June 1988), an Act of the US Congress that eliminated appeals as of right to the USSCt from lower state court decisions.

29 Editorial, 'The Best Lawyers Money Can Buy' New York Times (New York, 25 December 2014) <http://www.nytimes.com/2014/12/26/opinion/thebest-lawyers-money-can-buy.html?_r=0> accessed 31 March 2015. 
bring before her. ${ }^{30}$ Compounding this, moreover, is the prominent role of nongovernmental organizations and civil rights groups in fostering and financing constitutional litigation. ${ }^{31}$ Again, unlike in the case of the individual who unexpectedly finds himself embroiled in a tort or contract dispute, the typical civil rights nongovernmental organization is likely to search for attractive individual challengers of presumably unconstitutional legislation and to direct, coordinate and finance the subsequent constitutional litigation. ${ }^{32}$

The second factor that stacks up against depoliticization of the judiciary through the 'case or controversy' requirement is the tradition and practice of common law adjudication. ${ }^{33}$ The common law is judge made law. Common law judges adjudicate legal disputes brought before them and, in the absence of precedents, are free to set the law which will determine the outcome of the dispute before them. For example, if the downstream neighbor of an upstream landowner sues the latter claiming damages resulting from dumping waste in the river that flows through both of the properties involved, the judge will 'make law' upon deciding that there is liability for damages (or that there is not), under the specific circumstances of the case. Moreover, once the latter judge's decision is made, other judges confronted with similar disputes in the future would be obligated to treat the first judge's decision as precedent, but would still have a great deal of discretion in determining whether the precedent in question is controlling or distinguishable in terms of the case before them. To expand on the preceding example, is the upstream neighbor who dumps waste in the river liable only if he knew that the waste in question was toxic or regardless of such knowledge (assuming that the defendant in the first case was clearly aware that what he was dumping was toxic)?

30 Although the USSCt's freedom to choose constitutional cases for adjudication is in principle virtually unlimited, in practice the Court has been mindful to secure uniformity throughout the country on important constitutional questions. Accordingly, when lower courts are divided over important constitutional questions, including those pertaining to fundamental rights, the USSCt is more likely than not to accept for review a pertinent case that would allow it to promote constitutional uniformity throughout the country.

31 See Nancy Winemiller Basinger, 'Charities in Court: The Advocacy Efforts of Charitable Nonprofit Organizations in the Judicial Venue: When? How? And How Much?' (DPhil thesis, University of Georgia 2003).

32 Ibid.

33 For a more extended discussion of this point, see Rosenfeld, 'Constitutional Adjudication in Europe and the United States' (n 7) 648-9. 
Common law legal rules can be overridden by statutes, and not only have statutes to a large extent replaced common law judicial law making in the US, but the country's written constitution is, formally at least, much more like a statute than like an evolving juridical norm extracted from a string of relevant precedents. In spite of this, however, judicial interpretation in the US remains open-ended, leaving much room for common law-like judicial lawmaking. This is due principally to two cumulative factors: first, many key fundamental rights constitutional provisions, such as 'Due Process', 'Equal Protection' or the prohibition against 'Cruel and Unusual Punishments', are articulated at a very high level of generality, making for a broad array of plausible interpretatively driven concretizations that are often likely to divide the citizenry. For example, does equal protection protect or prohibit affirmative action resulting in preferential treatment in favor of historically discriminated against minorities? ${ }^{34}$ To this vastly open-ended constitutional articulation of key fundamental rights, one must add a second factor that operates to expand and magnify the consequences associated with the first factor. This second factor is the widespread judicial use of the open-ended characteristic common law interpretive approaches when confronting issues of statutory law. Thus, for instance, in a five-to-four decision, the USSCt interpreted an employment statute that prohibited discrimination against any individual on account of his/her race as being consistent with preferential treatment in the hiring of traditionally discriminated against racial minority employment candidates. ${ }^{35}$ In short, not only are many key statutory texts like US constitutional provisions akin in terms of generality to broad principles and standards that serve as guideposts in common law adjudication, but judicial interpretation in the US, whether statutory or constitutional, looms as still deeply anchored in the moorings of typical common law blending of judicial interpretation and law making.

The fourth and final feature of constitutional design identified above concerns the conception and formulation of fundamental rights included in the US Constitution. The original 1787 US Constitution contained very few individual rights provisions. Indeed, the latter were by and large

34 See, for example, City of Richmond v Croson 488 US 469 (1989) (contrast between USSCt's majority's conclusion that preferential treatment for racial minorities in heavily segregated construction industry is unconstitutional and Court's minority's assertion that such preferences are constitutional as a means to eradicate the present effects of past racial discrimination).

35 See United Steelworkers v Weber 443 US 193 (1979). 
limited to protection against ex post facto laws, ${ }^{36}$ against state impairment of contracts, ${ }^{37}$ and against curtailing or suspending the right of habeas corpus, except in cases of insurrection or invasion. ${ }^{38}$ The reasons for this dearth of fundamental rights were basically twofold: from an institutional standpoint, the federal government was meant to be one of 'limited and enumerated' powers, ${ }^{39}$ thus leaving most dealings between government and individuals in the hands of the federated states; from the standpoint of the dominant American political philosophy during the times of the country's founding generation, on the other hand, fundamental individual rights were understood in Lockean terms as natural, inalienable and pre-political, being thus essentially negative rights that required government non-intervention and non-interference. ${ }^{40}$ In other words, unlike in the Continental European tradition, in which fundamental rights are perceived as essentially positive and as requiring active state intervention to secure their enjoyment by the citizenry, for the American constitution-making generation (and for subsequent generations to a large extent) such rights were best conceived as pre-given, and government's proper role in relation to them, as strict confinement to a hands-off policy.

In spite of the strong Lockean underpinnings of the dominant conception of American fundamental rights, the founding generation was divided over whether a constitutional bill of rights would enhance or erode enjoyment of the natural rights to which each individual was thought to be entitled. ${ }^{41}$ Pursuant to a compromise reached among the 1787 constituents, the US Bill of Rights was adopted in 1791. Although judicial interpretation of the latter will be more extensively discussed in the second part below, two general points deserve brief mention here. First, the rights enshrined in the US Bill of Rights are overwhelmingly negative in nature. Thus, for example, the First Amendment provides that 'Congress shall make no law respecting an establishment of religion, or prohibiting the free exercise thereof; or abridging the freedom of speech or of the press .... ${ }^{42}$ And second, the USSCt made it clear early on that

\footnotetext{
36 US Constitution 1787, art I, s 9, cl 3.

37 Ibid., art I, s 10, cl 1.

38 Ibid., art I, s 9, cl 2.

39 See James Madison, The Federalist Papers (1788) N 45: The Alleged

Danger From the Powers of the Union to the State Governments Considered.

40 Ibid., N 10.

41 See Richard Beeman, Plain, Honest Men: The Making of the American

Constitution (Random House 2009) 341-3.

42 US Constitution 1787, Am I (1791).
} 
the Bill of Rights was applicable against the federal government but not against the states. ${ }^{43}$ Only much later, after the US Civil War and the adoption of the Fourteenth Amendment in 1868, did the protections of the US Bill of Rights became gradually nationalized and made applicable to the states. ${ }^{44}$ At present, by far most, but not all, of the rights protected in the US Bill of Rights have been adjudged applicable against the states. ${ }^{45}$ Moreover, in addition to US Bill of Rights, the Fourteenth Amendment - which through its Equal Protection clause first introduced constitutional equality in the US - currently provides an additional source of fundamental rights protection under the US Constitution. ${ }^{46}$

\subsubsection{Key Extrinsic Factors Bearing on the Distinctiveness of US Constitutional Adjudication}

Not only has the constitution been primarily cast as law in the US, in contrast to other polities, such as France, which have envisioned their constitution as being essentially political in nature, but also for Americans the constitution plays a key central role that has no equivalent anywhere else. ${ }^{47}$ Indeed, in the US the constitution figures prominently in the very construction of the nation and in the elaboration of its national identity. Whereas in the France of the 1789 Revolution, the state and a well defined, though not fully consolidated, nation preceded the constitution, in the US the 1787 Constitution launched the state and anchored a future nation whose contours and identity would take several generations to cement. ${ }^{48}$ To put it differently, whereas in most polities, the constitution builds upon a nation, its history and a distinct national identity, in the US it is the nation and national identity that have been framed by the constitution. In 1787, the present US Constitution was crafted in the

\footnotetext{
43 See Barron v Baltimore 32 US 243 (1833).

44 See Richard E Labunski, James Madison and the Struggle for the Bill of Rights (OUP 2006) 259.

45 See Bill of Rights Institute, 'Fourteenth Amendment: Incorporation (1868)' <http://billofrightsinstitute.org/educate/educator-resources/landmarkcases/incorporation/> accessed 31 March 2015.

46 All the post-civil war amendments, which include the Thirteenth (1865) which prohibits slavery and the Fifteenth (1870) which grants the franchise to African-American males, secure additional fundamental rights, but for purposes of examining issues pertaining to judicial interpretation, the Fourteenth far overshadows the other two.

47 See Rosenfeld, The Identity of the Constitutional Subject (n 8) 73, 293, n 2 .

48 Ibid., 158-63.
} 
name of a 'We the People' who would not cohere into the present American nation for more than a century as it first had to abolish slavery and to absorb various massive future waves of immigrants. The US motto E Pluribus Unum and the associated metaphor of the American 'melting pot' 49 depend for any meaningful degree of realization on convergence around the US Constitution and the values and vision it projects.

Every nation-state with a working constitution projects a particular national identity that is distinct from its constitutional identity. ${ }^{50}$ Moreover, both of these kinds of identity are, to use Benedict Anderson's characterization, imagined. ${ }^{51}$ Though they remain distinct from one another, national identities and constitutional identities are intertwined and overlapping. ${ }^{52}$ In most cases, national identity can be conceived independently from the constitution or constitutional identity. For example, it is not difficult to imagine France or Germany as projecting a rich and varied national identity based on history, culture and common destiny without reference to their respective constitutions. In stark contrast, without reference to the US Constitution, it is difficult to envisage a plausible national identity for the US. This does not mean that national and constitutional identities do not remain distinct in the case of the US - for example, some of US policies and actions in pursuit of the post 9/11, 2001 'war on terror' may be integrated within the country's self-image as a nation while defying the US's constitutional selfperception as the foremost defender of human rights. But the inseparability of the US's national and constitutional identities underscores both that the constitution plays a central role in the preoccupations of the citizenry and that it has an important and ubiquitous role in carving out the nation's evolving self-image.

The centrality of the constitution as law coupled with the close intertwining of national and constitutional identity has a crucial impact on the role and place of constitutional adjudication in the US. As often noted, '[n]early all of the most controversial issues in American politics ... end up before the [USSCt]', 53 where they await final and authoritative resolution by judges appointed for life and hence presumably above

\footnotetext{
49 See Will Kymlicka, Multicultural Citizenship (OUP 2001) 14.

50 See Rosenfeld, The Identity of the Constitutional Subject (n 8) 11-12.

51 See Benedict Anderson, Imagined Communities: Reflections on the Origin and Spread of Nationalism (Verso 1991).

52 See Rosenfeld, The Identity of the Constitutional Subject (n 8) 11-12.

53 Jeffrey Rosen, 'The Court and Democracy' (The Supreme Court, December 2006) <http://www.pbs.org/wnet/supremecourt/democracy/history.html> accessed 31 March 2015.
} 
the fray of politics and of its continuous give and take. Accordingly, Americans have a tendency to constitutionalize politics. Ideally, such constitutionalization would remove the most important and potentially most divisive issues, such as abortion, affirmative action, the clash between secularism and religion, gay marriage, assisted suicide, the death penalty, and many others, from the political arena. In practice, however, throughout US history, the constitutionalization of politics has seemingly inevitably gone hand in hand with the politicization of the constitution or, more precisely of the constitution as law. In short, political disputes tend to become constitutional issues and, as such, questions of (constitutional) law. But that, in turn, seemingly inevitably politicizes constitutional adjudication. What remains an open question at this point - which will be addressed in the course of what follows - is: Does the judicial politics associated with constitutional interpretation somehow ultimately rise above politics, amount to just one more iteration of ordinary politics, or does it represent an altogether different kind or dimension of sui generis politics, largely confined to the realm of constitutional adjudication?

\subsection{FUNDAMENTAL RIGHTS AS THEY EMERGE THROUGH JUDICIAL INTERPRETATION OF THE US CONSTITUTION}

The combination of conceiving constitutionally enshrined fundamental rights as negative rights and of likening them to pre-political, innate and inalienable Lockean natural rights opens the way to casting their judicial interpretation and application as plausibly rising above all politics. Indeed, if free speech requires maintaining a state hands-off policy, and if every reasonable and responsible person is supposed to agree on the contours of the inalienable pre-political right to free speech, then all judges ought to be able to resolve free speech cases without any recourse to politics. Moreover, consistent with this, US constitutional adjudication in the context of a Lockean conception of rights would bear one crucial analogy to the Kelsenian vision of the apolitical constitutional judge operating within the ambit of the civil law. Both American fundamental rights adjudication and Continental European constitutional review could function in ways that would altogether sever them from politics: in the former case, by striking down laws that trampled on pre-political rights with rationally discoverable content; in the latter, by confining constitutional adjudication to process-based questions - for example, was the 
parliamentary law being challenged adopted by the constitutionally requisite majority ${ }^{54}$ In short, in both cases, the judicial actor would function as an apolitical negative legislator: in the Kelsenian European context by confining the constitutional judge to a policing process; in the Lockean American context, by charging judges with striking down unwarranted state abridgments of rationally ascertainable pre- and extrapolitical rights.

Just as the Kelsenian metaphor of the negative legislator does not extend to the civil law constitutional adjudicator who is called upon to strike down legislation that contravenes constitutionally protected fundamental rights, so too the Lockean ideal embodied in natural rights collapses when confronted with the realities of fundamental rights adjudication. There is, however, one major difference between the judge as negative legislator and the judge as natural rights protector. Framing the constitutional adjudication function in terms of negative adjudication seems entirely plausible so long as the judicial review involved is limited to constitutional process based determinations. In contrast, natural rightsbased adjudication seems wholly implausible in principle to the extent that the rights encompassed within natural law, such as liberty and property, constitute what philosophers have labeled 'essentially contested concepts'. ${ }^{55}$ In other words, all may agree that liberty and property are fundamental rights but there are bound to be inevitable disagreements concerning their precise meaning and concrete reach. Accordingly, judicial interpretations of such fundamental rights are bound to differ with the consequence that they will inevitably loom as contestable and that their legitimacy will in many cases become contested.56

The contradiction between the assumed transparency of pre-political natural rights and the inevitable discretion that judges enjoy when interpreting them in their constitutional incarnation exacerbates the 'countermajoritarian' difficulty and the 'unchecked checker' problem outlined above. The constitutional adjudicator speaks in the name of all, but decides in agreement with the values of some and against those of

54 Hans Kelsen, Introduction to the Problems of Legal Theory (OUP 1992).

55 Michel Rosenfeld, 'Constitutional Identity' in Michel Rosenfeld and András Sajó (eds), The Oxford Handbook of Comparative Constitutional Law (OUP 2012) 756.

56 A salient example is provided by Roe v Wade, the 1973 USSCt abortion decision, the legitimacy of which has now been contested for over 40 years. See, for example, Sydney Lupkin, 'Abortion 40 Years after Roe v. Wade' ABC News (18 January 2013) <http://abcnews.go.com/Health/roe-wade-abortion-america40-years/story?id=18242770> accessed 31 March 2015. 
others. Fundamental rights controversies are taken to judges to rise above politics, but end up mired in other controversies. Are the latter reducible to mere politics? Or do they become caught in something else, such as moral disagreement or some different order of politics exclusively related to judicial craft and ideology?

On the premise that natural rights are discoverable to all who are sensible and who rely on reason, they presumably need no listing - or, at least, no exhaustive listing - in the written constitution. On the other hand, however, to the extent that natural rights inevitably turn out to be essentially contested in practice, not listing them or listing them in the most general and abstract terms within the text of the constitution only exacerbates their indeterminacy and their seemingly inexhaustible pliability to the interpretive whims of their judicial interpreters. A prime example of this is furnished by the Ninth Amendment to the US Constitution, which is part of the 1791 US Bill of Rights, and which provides: 'The enumeration in the Constitution, of certain rights, shall not be construed to deny or disparage others retained by the people.' This Amendment has been invoked to provide judicial recognition to an unenumerated broad constitutional right to privacy that extends to the freedom to use contraceptives, ${ }^{57}$ to have an abortion, ${ }^{58}$ and to engage in consensual adult homosexual sex. ${ }^{59}$ Moreover, to underscore the seemingly unlimited plasticity of the Ninth Amendment, it bears emphasizing that its invocations have prompted strong dissents with altogether radically different interpretations. Thus, the dissenting justices in Griswold accused their colleagues in the majority of using 'natural justice' to fashion fundamental rights according their own subjective predilections and interpreted the Ninth Amendment as protecting the federated states from 'federal invasion'. ${ }^{6}$ Consistent with the latter view, far from granting additional unenumerated rights, the Ninth Amendment ought to be understood as protecting federated state legislative majorities from any national constitutional constraints issued from any federal constitutional fundamental right that is not explicitly inscribed in the text of the US Constitution.

57 See Griswold v Connecticut 381 US 479 (1965) (Goldberg J, concurring).

58 See Roe v Wade 410 US 113 (1973).

59 See Lawrence v Texas 539 US 558 (2003), a six-to-three decision overruling Bowers v Hardwick 478 US 186 (1986), a five-to-four decision holding that the right to privacy does not bar a state from criminalizing consensual adult homosexual sex and providing for punishment of up to 20 years in prison.

60 Griswold (n 57) (Black J, dissenting). 
The interpretive rift between the majority and dissenting justices in Griswold was not limited to the Ninth Amendment, but it also extended to the Due Process clause of the Fourteenth Amendment, which provides that no state 'shall deprive any person of life, liberty or property, without due process of law'. As a matter of fact, some of the majority justices interpreted the Due Process clause as guaranteeing substantive rights, including privacy, ${ }^{61}$ whereas the dissenters interpreted it in purely procedural terms and linked its use by their colleagues in the majority to the latter's reference to the Ninth Amendment. In the dissenters' view, both of these amendments were being invoked in vain by the majority to create a 'natural justice' cover to mask their giving expression to their subjective preference. ${ }^{62}$ In short, just as in the case of the open-ended Ninth Amendment, the very broadly stated Due Process clause emerges in Griswold as being susceptible of diametrically opposed judicial interpretations.

To recapitulate: both in terms of their specification and their interpretation, US constitutionally protected fundamental rights emerge in the context of a series of dichotomies that give rise to a seemingly insurmountable sequence of paradoxes and contradictions. The principal dichotomies at stake include: law versus politics; natural rights (or their contemporary progeny ${ }^{63}$ ) versus positivism; common law versus statutes (with the Constitution formally resembling a statute but acquiring determinate content much like any other common law subject matter, such as contracts or torts); predictability versus fairness in the struggle to conform to the dictates of the rule of law; substance versus procedure; originalism versus adaptation to meet generational needs; and majoritarianism versus countermajoritarianism - or, more precisely, protection of clearly defined uncontestable countermajoritarian rights, such as judicial protection against legislative interference with free political speech, versus contestable such protection unwarrantedly leading to judicial expansion, or downright invention, of clearly contestable antimajoritarian rights.

Navigating these various dichotomies is certainly a daunting task which is somewhat rendered more manageable on many occasions due to intrinsic or extrinsic factors that happen to reduce the number of

61 Ibid., (Harlan J, concurring).

62 Ibid., (Black J, dissenting).

63 Ronald Dworkin's conception of fundamental rights under the US Constitution may be regarded as a contemporary version of a natural rights perspective. See Ronald Dworkin, Taking Rights Seriously (Harvard University Press 1977). 
operative dichotomies at play. Where there is large societal agreement or indifference about a matter, dichotomies involved in constitutional adjudication may vanish beneath the surface or remain dormant. For example, whereas whether racial apartheid was permitted or prohibited under the Equal Protection clause was a highly disputed matter for over a half century, ${ }^{64}$ it is no longer an issue and the dichotomies that animated the heated controversy that ended over 50 years ago have now completely receded. Indeed, even Justice Scalia, the fiercest champion of originalism, which requires judicial interpretation of the Constitution to be confined to the meaning it had or could have had for the generation of the framers, is unequivocally against racial apartheid, and hence in conflict with the views that prevailed in 1868 when the Equal Protection clause was adopted. ${ }^{65}$ There may also be intrinsic factors in given cases that blunt or render key dichotomies inoperative. It is not difficult to imagine cases where matters of substance and procedure merge, such as in the exclusion of African-Americans from juries, or where originalists and adaptionists concur as certain relevant standards have not changed over the centuries. Thus, both in 1791, when the US Bill of Rights was adopted, and up to the present, a virtually unanimous consensus has prevailed concerning the proposition that the Free Speech clause of the First Amendment extends to political speech that is critical of existing domestic government policy. 66

In order to better focus on the major practical and legitimacy related issues surrounding US judicial constitutional adjudication, the following summary and selective review of some of the USSCt's most notorious, and in many instances, most criticized decisions will focus on cases that exacerbate rather than smoothly manage or minimize those among the above listed dichotomies that emerge as pertinent under the unique set of circumstances involved. Doing so will highlight the tensions and fault lines characteristic of US constitutional adjudication. However, in so doing, one should not lose sight that the overall level of acceptance and legitimacy of the USSCt in the US depends on placing it in its full

64 Compare Plessy v Ferguson 163 US 537 (1896) (racial apartheid held constitutional so long as 'separate but equal' accommodations provided for blacks and whites) with Brown v Board of Education 347 US 483 (1954) (racial segregation in public education held unconstitutional).

65 Ronald Turner, 'Was "Separate but Equal" Constitutional?: Borkian Originalism and Brown' (1999) 4 Temp Pol \& Civ Rts L Rev 229.

66 See, for example, Robert Bork, 'Neutral Principles and Some First Amendment Problems' (1971) 47 Ind LJ 1. 
context which comprises cases that are little controversial alongside cases that are so contested as to divide the American citizenry over generations. ${ }^{67}$

In the broadest terms, the USSCt's greatest challenge in constitutional adjudication is to reconcile an eighteenth century bill of rights with the constitutional challenges and aspirations of the twenty-first century. Some of the most salient dichotomies, such as that between natural rights/law versus positivism, trace back to the beginning of the USSCt's trajectory and have evolved without resolution through the centuries. Thus, already in 1798, in one of its earliest decisions, Calder v Bull, ${ }^{68}$ the USSCt justices were divided, with Justice Chase placing natural law/ rights above the Constitution and Justice Iredell adopting the positivist standpoint and declaring that there is no higher law than the Constitution. Iredell's views prevailed, but the dichotomy has since been displaced rather than resolved. The US Constitution has been accepted as the highest law, but both the unenumerated and the broadly articulated fundamental rights that it has slated for protection have been interpreted in natural rights fashion by some and in positivistic terms by others as the above discussed rift between the majority justices and the dissenters in the 1965 Griswold decision attests to. ${ }^{69}$

The dichotomy between substance and procedure in the context of fundamental rights cases was first faced squarely by the USSCt in its infamous 1857 Dred Scott decision. ${ }^{70}$ Pairing down a complex set of circumstances to its essentials, Dred Scott was a slave who was brought by his master from the southern state of the latter to a federal territory. Pursuant to a federal statute, Dred Scott became emancipated upon entering federal territory. Subsequent to that emancipation, however, Dred Scott returned to the state where he had been a slave and ownership over him was reclaimed on the grounds that his emancipation had violated the slave owner's property rights under the Due Process clause of the Fifth Amendment. ${ }^{71}$ Had the USSCt interpreted the Due Process clause in purely procedural terms, it would have had to uphold the emancipation on the grounds that the federal emancipation statute at

\footnotetext{
67 One such case already mentioned is Roe v Wade (1973).

683 US 386 (1798).

69 Griswold (n 60-62 and accompanying text).

70 See Dred Scott v Sanford 60 US 393 (1857).

71 The Due Process clause of the Fifth Amendment applies against the federal government whereas that of the Fourteenth Amendment affords protection against the several states.
} 
stake had satisfied all the relevant process based constitutional requirements and that all valid federal laws prevail over inconsistent state laws by virtue of US Constitution's Supremacy clause. ${ }^{72}$ The Court chose, however, to interpret the Due Process clause in substantive terms and to hold the federal emancipation law unconstitutional for depriving the slave owner of his private property though the latter had done nothing to justify interference with his lawfully acquired and used property. The Due Process clause protects liberty rights as well property rights, and one might have thought accordingly, that once the USSCt had decided to opt for a substantive approach over a procedural one, it could have pitted the emancipated former slave's liberty interest against his former owner's property right - and perhaps even have ruled that in the case at hand the liberty interest involved prevailed over the property interest invoked against it. That latter option was nonetheless precluded by the USSCt's holding that members of the slave race were neither persons nor citizens under the US Constitution. Using what may be characterized as an originalist argument, the USSCt stressed that the Constitution's framers believed that the slave race was 'so far inferior, that they had no rights which the white man was bound to respect'. ${ }^{73}$ Besides being shameful, scandalous, morally repugnant and downright destructive to the extent that it might have helped precipitate the US Civil War, Dred Scott dramatically exemplifies the actual convergence of several dichotomies besides the one between substance and process. These include the one between originalism and adaptionism, the one between politics and judicial philosophy, and the one between natural rights (for example, property) and positivism. Moreover, these dichotomies play an interrelated role in the context of the case and raise as many questions as they answer. For example, there is a clear political cleavage (as well as a moral one) between the slave owning state concerned in the case and the federal government. Also superimposed upon that latter dichotomy is the one regarding judicial philosophy. And, given that the originalist interpretive stance that prevailed seemed perfectly aligned in terms of consequences with the politics of slave owning, should questions of judicial philosophy be regarded as proxies for, or subordinated to, politics or as independent though sometimes convergent?

There are two additional factors that contribute to the shaping of American exceptionalism in constitutional adjudication: the first derives from the US conception of fundamental rights as negative and Lockean

72 US Constitution 1787, art VI, cl 2.
73 Dred Scott (n 70) 407. 
in nature; the second, from the use of federalism based claims as substitutes for, or complements to, fundamental rights ones. As already pointed out, Lockean negative rights evoke a government hands-off or no trespass vision and are accordingly articulated in absolutist terms. This is in sharp contrast with more recent iterations of fundamental rights protections. Thus, for example, the Canadian 1982 Charter provides that rights it protects are subject to "such reasonable limits prescribed by law as can be demonstrably justified in a free and democratic society'. ${ }^{74}$ Similarly, the European Convention on Human Rights stipulates limitations concerning most of the rights it protects. Freedom of religion rights, for example, 'are subject to such limitations as are prescribed by law and are necessary in a democratic society in the interests of public safety, for the protection of public order, health or morals, or for the protection of the rights or freedoms of others' ${ }^{75}$ These limitation clauses provide interpretive guidance, give backing to the judicial use of the proportionality standard in constitutional adjudication, and suggest judicial balancing of competing rights claims. Operating in the absence of any such limiting clause coupled with the predominance of Lockean negative rights, in contrast, affords the US constitutional adjudicator with greater interpretive latitude and has arguably resulted in the nearly complete absence of recourse to proportionality in American constitutional adjudication. ${ }^{76}$ Furthermore, American constitutional jurisprudence is remarkable for its lack of tools or of consideration of competing constitutional fundamental rights claims. This is well illustrated in cases in which constitutional interests of different members of the same family come into conflict. In Troxel v Granville, ${ }^{77}$ the USSCt adjudicated a conflict over grandparent visitation rights where the mother of the child opposed visitation by the parents of the deceased father from whom she had become widowed. A state law that the mother challenged as unconstitutional provided for grandparent visitation rights. Whereas the USSCt could have cast the controversy in terms of a clash among the respective constitutional privacy rights of the mother, the grandparents and the child, it resolved the case by pitting the constitutional right of the mother

74 Canadian Charter of Rights 1982, s 1.

75 Convention for the Protection of Human Rights and Fundamental Freedoms 1950, art 9.

76 See, for example, Michel Rosenfeld, 'Judicial Balancing in Times of Stress: Comparing the American, British and Israeli Approaches to the War on Terror' (2006) 27 Cardozo L Rev 2083.

77530 US 57 (2000). 
against the state interest advanced in the grandparent visitation legislation. Unsurprisingly, the USSCt held that the mother's constitutional right prevailed over the conflicting state interest. One can of course imagine a different result if the grandparents' interest had been cast as constitutional rather than as statutory and if the child's constitutional interest in an ongoing relationship with his closest paternal blood relatives had been factored in.

The last factor relating to American exceptionalism in constitutional adjudication that bears mentioning here is that concerning the use of federalism considerations to expand or limit the scope of fundamental rights. As already noted, before the US Civil War, the US Bill of Rights was adjudged solely applicable against the federal government and only with the adoption of the post Civil War amendments ${ }^{78}$ did fundamental rights gradually became applicable against the federated states as well. ${ }^{79}$ Shortly after the adoption of the post Civil War amendments, the USSCt interpreted them very narrowly and reasoned explicitly in its 1873 Slaughter-House Cases $^{80}$ decision that to do otherwise would lead to undue interference with the sovereignty rights of the federated states. ${ }^{81}$ Although fundamental federal constitutional rights have become since applicable against the states almost in their entirety, claims of 'state rights' have been historically interposed against expansive interpretations of fundamental rights. The 'states rights' appellation is a misnomer as, strictly speaking, it is a matter of 'state powers' whenever the USSCt is urged to interpret a fundamental right narrowly lest it sanction federal trampling on state sovereignty. Be that as it may, the use of 'state rights' rhetoric allows masking racist, sexist or homophobic positions, for example, in the guise of seeking protection for the integrity of the sub national democratic units enshrined in the Constitution. ${ }^{82}$

78 The Thirteenth Amendment was adopted in 1865, the Fourteenth in 1868, and the Fifteenth in 1870.

79 See above (n 43-45 and accompanying text).

8083 US 36 (1873).

81 Ibid., 121-3.

82 See the discussion of the Hollingsworth and Windsor cases below (n 108-117 and accompanying text). In principle, federalism based initiatives can be shaped to enhance fundamental rights protection as well as to constrain it. Significantly, in recent times, as the USSCt has embraced more restrictive interpretations of certain fundamental rights, certain states have proceeded to afford more expansive protection of the rights in question within their own borders in reliance on their own subnational constitution. See, for example, Lina R Carbuccia, 'New York's Grant of Greater Fifth Amendment Rights to Sexual Predators in SOMTA Proceedings' (2012) 28 Touro L Rev 857. 


\subsection{USSCT CONSTITUTIONAL ADJUDICATION IN HIGHLY CONTROVERSIAL FUNDAMENTAL RIGHTS CASES: RESTRICTIVE VERSUS EXPANSIVE APPROACHES}

As it is of course impossible to deal adequately with even a highly select list of the USSCt's most controversial fundamental rights cases within the scope of the present undertaking, only brief reference will be made to some key cases in order to set the stage for the discussion of the two recent same-sex marriage cases that will be examined in greater detail. The focus on these two 2013 cases seems well justified for a number of reasons: the two cases were five-to-four decisions, with the justices splitting in different configurations; same-sex marriage issues fit within the Griswold line of cases involving unenumerated rights and substantive due process; the US politics concerning homosexual rights and the popular acceptability of same-sex marriage have been evolving at a very rapid pace; sexual orientation issues have risen at the forefront of the heated US controversy over citation to foreign authorities - particularly, European ones - in constitutional adjudication; and the two cases involved squarely raise controversial issues relating to the proper interplay between fundamental rights, separation of powers and federalism.

\subsubsection{Key Cases in Delimiting the Most Salient Controversies in US Constitutional Adjudication}

The two most important cases that have framed the US constitutional treatment of race relations after the emancipation from slavery and the embrace of constitutional equality through adoption of the Equal Protection clause are Plessy v Ferguson (1896) ${ }^{83}$ and Brown v Board of Education (1954). ${ }^{84}$ In Plessy, the USSCt adopted the 'separate but equal' standard thus casting apartheid as consistent with constitutional equality. To reach this result, the USSCt conceived constitutional equality among the races to extend to civil and political rights, but not to social rights that would call for racial integration of railroad cars and of other public facilities. Only Justice Harlan dissented and penned the famous dictum that 'the Constitution is color blind'. ${ }^{85}$ To the contemporary reader, the decision in Plessy seems heavily influenced by racist mores

\footnotetext{
83163 US 537 (1896).

84347 US 483 (1954).

85 Plessy (n 83) 559.
} 
according to which mingling between the races emerges as socially undesirable if not downright unacceptable. More than half a century later in a unanimous decision, the USSCt held in Brown that racial segregation in public schools was unconstitutional, thus launching a veritable constitutional revolution. Brown not only struck down laws that mandated school segregation, but also decreed that those state agents responsible for segregation undertake full desegregation of the schools under their jurisdiction - a process that led to a large volume of litigation over four decades and that has not yet come to full fruition. ${ }^{86}$ In contrast to Plessy, Brown went squarely against the mores of the states that mandated segregation and prompted some dramatic resistance against integration that required federal marshals to forcefully impose racial integration against obstructing state officials. ${ }^{87}$ Brown can be read as imposing morals over mores and as having fairness trump predictability in terms of rule of law concerns. Moreover, it has been suggested that the holding in Brown was to a significant degree influenced by US foreign relations concerns as glaring images of racial segregation tainted US's claims to be a champion of freedom and human rights in the context of the battle of ideologies prevalent during the Cold War. 88

The ongoing bitter political divisiveness unleashed by the USSCt's decision in Roe v Wade is ubiquitous, but one key aspect of the decision requires further brief mention as it bears particularly salient interpretive consequences. Roe would have been inescapably controversial as it recognized an unenumerated right to abortion, a subject over which Americans have been passionately divided. But even under these circumstances, the Roe decision might have been much less inflammatory had the USSCt strictly adhered to the constraints imposed by the "case or controversy' requirements. In Roe, a woman who wanted to have an abortion challenged a Texas law that criminalized all abortions except those undertaken to save the life of the mother. The USSCt could have simply struck down the Texas law, and specified that as the right to an abortion is constitutionally protected, the state would have to advance a compelling interest for any limitation it sought to impose on the exercise of that right. That may have been enough for the plaintiff in Roe to obtain relief and for further specifications of the right involved to await further state legislation and future cases raising specific objections to the latter.

86 See The Editors of Black Issues in Higher Education, The Unfinished Agenda of Brown v. Board of Education (J Wiley and Sons 2004).

87 See James T Patterson, Brown v. Board of Education: A Civil Rights Milestone and Its Troubled Legacy (OUP 2001) 107.

88 Ibid., 2. 
Instead of that, however, the USSCt acted pretty much as a legislator, dividing pregnancy into three trimesters and the granting a woman an unrestricted right to abortion in the first trimester, authorizing limited state restrictions in the second trimester and allowing for all state restrictions save when the mother's life or health is endangered in the third semester. Whereas the contrast between strict adherence to the "case or controversy' constraint and the broad lawmaking approach in Roe is dramatic, the tension between tailoring constitutional adjudication to particular facts and fashioning it so as to provide greater guidance and unity within the decentralized US system of constitutional review is an inescapable one. And although more general decisions going clearly beyond the facts at hand will in most cases seem more political, there is much to be said for the need for USSCt constitutional adjudication relating to fundamental rights to provide meaningful unity throughout the country and sufficient guidance to judges and other official actors charged with interpreting and protecting fundamental rights.

The line between judicial philosophy and ordinary politics may often be difficult to draw, but seems conceptually sound. A judge may be an originalist or devoted to a restrictive interpretation of fundamental rights, or else one who believes in reconciling constitutional interpretation with the morals and the mores of the present generation and taking an adaptive and expansive approach to fundamental rights and yet adjudicate without regard for the political consequences or impact of her decision. For example, a judge may have a restrictive view of fundamental rights and of federal as opposed to state powers, but that would commit her to constitutionally upholding politically conservative policies, such as bans on abortion as well as politically progressive ones, such as legalization of assisted suicide.

Two of the most controversial recent USSCt decisions, Bush v Gore $(2000)^{89}$ and Citizens United v Federal Election Commission (2010)90 may at first appear to belie the distinction between judicial philosophy and politics, but upon further examination provide an excellent illustration of the proposition that the distinction in question is conceptually sound and yet at the same time difficult to maintain in practice. Both decisions undoubtedly had a profound political impact: Bush v Gore practically handed the contested 2000 US presidential election to George W Bush, and that by a five-to-four decision in which all the justices in

\footnotetext{
89531 US 98 (2000).

90558 US 310 (2010).
} 
the majority happened to have been nominated by Republican presidents; 91 and Citizens United, which was also a five-to-four decision, struck down a federal law that limited corporate contributions in support of political candidates through television commercials and other means on the grounds that such law violated free speech rights, thus giving corporate interests virtually unrestrained power to disproportionately influence the outcome of elections. The judicial handing over the 2000 election to Bush and the USSCt's equating of money to speech have been widely criticized and have cast the Court in a particularly bad light. ${ }^{92}$ Nevertheless, the two cases are clearly distinguishable along the judicial philosophy versus politics divide.

In Bush v Gore, the five justices who handed the presidency to Bush departed from their restrictive judicial philosophy which had hitherto led them to strike down an unusually high number of immensely popular federal laws - including the prohibition of possession of guns in schools $^{93}$ and the law tackling violence against women on a nationwide basis 94 - in order to deviate from one of the firmest and longest standing pillars of US federalism honored consistently by restrictive and expansive judicial interpreters alike. Indeed, it is a mainstay of American federalism that the highest state court is the authoritative interpreter of that state's law and that federal judges are bound to conform to such highest state court's interpretation when considering the (federal) constitutionality of any such law. In spite of this, however, five USSCt justices in fact handed the election to Bush by ordering an end to the recount of Florida voting ballots which had been imposed by the Florida Supreme Court based on its interpretation of Florida's election law. In order to reach the result they did, these justices had to substitute their own interpretation of the relevant Florida law for that of that state's highest court. And this is precisely what the USSCt majority did. Furthermore, there was yet another glaring anomaly in the USSCt decision which was not outcome

91 For an extended account and critique of the USSCt's Bush v Gore decision, see Michel Rosenfeld, 'Bush v. Gore: Three Strikes for the Constitution, the Court and Democracy, But There is Always Next Season' in Arthur Jacobson and Michel Rosenfeld (eds), The Longest Night: Polemics and Perspectives on Election 2000 (University of California Press 2002) 111. The discussion that follows is largely based on the account provided in the just cited work.

92 See, for example, Adam Liptak, 'Supreme Court Gets a Rare Rebuke, in Front of a Nation' New York Times (New York, 28 January 2010) <http:// www.nytimes.com/2010/01/29/us/politics/29scotus.html> accessed 31 March 2015.

United States v Lopez 514 US 549 (1995).

United States v Morrison 529 US 598 (2000). 
determinative, ${ }^{95}$ but which figures as strong evidence of politics taking over standard judicial practice. Indeed, the USSCt majority held that the disparity in the means of recounting votes accepted by the Florida Supreme Court violated the equal protection rights of Florida voters, but specified that its decision on this issue should not be construed as a judicial precedent in the context of future elections. Arguably, for a responsible judge, serious consideration that present decisions will serve as future precedents provides a significant buffer against fashioning judicial results solely geared to the politics of the moment. If the equal protection holding in Bush v Gore were to become a precedent for future presidential elections, it would have to require a complete overhaul of the way in which Americans vote. In 2000, in Florida alone, there were 67 electoral districts with a variety of different ways of recording and counting votes leading to citizens in different districts having measurably different probabilities that their vote would be properly counted.

The equating of speech and money in Citizens United is also consistent with an elitist brand of American conservative politics that promotes corporate interests and that abhors state policies that have a redistributive effect. Unlike in the Bush v Gore instance, however, judicial philosophy and ideology standing alone afford a plausible justification to the holding in Citizens United. Two related factors account for this latter proposition. The first of these is American exceptionalism in the context of free speech jurisprudence. Not only, as noted above, does the US Bill of Rights enshrine free speech rights that are articulated in absolute terms, but also US protection of such rights has been much more extensive than those promoted by most other constitutional democracies. ${ }^{96}$ The second factor, in turn, derives from the Lockean tradition in the conception of fundamental rights. For Locke himself, natural rights were conceived as flowing from a broad conception of property that weaves together individual dominion over his or her person, thoughts, conscience, beliefs

95 Even if the methods of vote recount accepted by the Florida Supreme Court were unconstitutional, the USSCt could have prescribed federally acceptable standards which would have allowed Florida to restart the recount from scratch and still meet all the pertinent deadlines for formally submitting the results of the recount to the US Congress which has the constitutional task of providing final certification of the outcome of presidential elections. See US Constitution 1787, Twelfth Amendment.

96 See Michel Rosenfeld, 'Hate Speech in Comparative Perspective: A Comparative Analysis' (2003) 24 Cardozo L Rev 1523. 
and possessions. ${ }^{97}$ Viewed accordingly, keeping in mind the metaphor of the individual as sovereign over his land, his crops and his pursuit of happiness within his own delimited space, it seems perfectly logical to regard one's money and one's ideas as inextricably linked. To be sure, for many this Lockean scenario cannot be credibly transplanted from its eighteenth century pre-industrial original setting to the contemporary world dominated by multinational corporations controlling wealth and resources that far exceed those of many nation-states. Be that as it may, the dispute between the Lockean speech absolutists and those seeking to achieve a proportionate balance between free speech and the integrity of the democratic process can be construed as tracking the conflict between originalists and adaptionists and that between the respective proponents of conflicting philosophies of fundamental rights. In sum, even if in practice it is impossible to determine whether politics shapes judicial philosophy or vice versa, in theory it remains possible to cast the two as distinct.

\subsubsection{The USSCt 2013 Same-sex Marriage Cases: Judicial Resolution or Political Deferral?}

The US political and constitutional landscape regarding homosexual rights, sexual orientation discrimination, and same-sex marriage has recently evolved at a very rapid rate. In 1986, the USSCt determined in a five to four decision in Bowers v Hardwick ${ }^{98}$ that punishment of up to 20 years in prison for engaging in consensual adult homosexual sex did not violate the constitutional privacy right recognized in Griswold. Bowers was overruled six to three in the 2003 Lawrence v Texas ${ }^{99}$ case which specified that privacy rights encompassed homosexual as well as heterosexual consensual adult sex. In between these two decisions, in 1996 in Romer $\mathrm{v}$ Evans, ${ }^{100}$ the USSCt struck down on equal protection grounds, a state constitutional amendment specifically authorizing discrimination based on sexual orientation in relation to dealings not involving sexual relationships. ${ }^{101}$ At around the same time, same-sex marriage came

97 John Locke, Second Treatise of Government (first published 1689, Simon and Brown, 3rd edn, 2012) ch 5.

98478 US 186 (1986).

99539 US 558 (2003).

100517 US 620 (1996).

101 The state involved was Colorado where homosexual sex was legally permissible at the time of the adoption of the challenged state constitutional amendment. See Romer (n 100) 635. 
suddenly upon the national legal and political scene following the 1993 decision by the Supreme Court of Hawaii, which decreed that its state constitution's own Equal Protection clause made it unconstitutional not to extend the right to marry to same-sex couples in Baehr $\mathrm{v}$ Lewin. ${ }^{102}$ Following that decision, fear set in that Hawaii would soon legalize same-sex marriage and that homosexuals would travel en masse there, get married and then return to their states of residence demanding that their marriages be recognized under the Supremacy clause of the US Constitution the same way as heterosexual marriages have been all along. ${ }^{103}$ To prevent this, the US Congress enacted the Defense of Marriage Act (DOMA) in 1996. ${ }^{104}$ Among other things, DOMA allowed states not to recognize same-sex marriages performed under the law of sister states and excluded lawful same-sex married couples from federal benefits available to their heterosexual counterparts. In the end, Hawaii did not legalize same-sex marriage in the aftermath of Baehr, but Massachusetts did so after its highest court ruled the same way under its own state constitution in Goodridge v Department of Public Health ${ }^{105}$ decided in 2003. Since then, several states have followed suit and, by the time the USSCt squarely considered the constitutionality of same-sex marriage, 36 states and the District of Columbia provided for same-sex marriage. ${ }^{106}$

In 2015 the USSCt decided by a five to four vote that same-sex marriage was constitutionally protected under the Due Process and Equal Protection clauses of the US Constitution's Fourteenth Amendment, ${ }^{107}$ but a bare two years earlier in two same-sex marriage cases before it the Court deliberately avoided doing so. Although the importance of these two 2013 cases decision discussed below is now significantly eclipsed by the Obergefell decision, they nonetheless fully retain their worth as

10274 Haw 530 (1993).

103 US Constitution 1787, art VI, cl 2. In the US eligibility and qualifications for marriage are a matter of state as opposed to federal law. Moreover states deviate somewhat from one another in the criteria they set. Nevertheless, all states have to accept the validity of a heterosexual marriage concluded in a sister state under criteria that the former state does not accept as a basis for marriage under its own requirements. For example, a state may not allow first cousins to marry, but must recognize a marriage among first cousins legally entered into in a sister state with no equivalent ban.

104 Pub L 104-199, 110 Stat 2419, enacted 21 September 1996, 1 USC para 7 and 28 USC para $1738 \mathrm{C}$.

105798 NE 2nd 941 (Mass 2003).

106 See <http://www.freedomtomarry.org/states/> accessed on 31 March 2015.

107 Obergefell v Hodges, 135 S. CT. 2584 (2015). 
illustrative of an unusually high number of interpretive and institutional dichotomies and paradoxes.

The two cases in question were decided on the same day. The first of these, Hollingsworth v Perry ${ }^{108}$ dealt with a rather messy state of affairs relating to same-sex marriage in California. In 2008, the California Supreme Court ruled as had its Hawaii and Massachusetts counterparts as mentioned above. In California, however, the decision was followed several months later by adoption pursuant to a state referendum, known as Proposition 8, of a constitutional amendment that explicitly limited legal marriage to unions between a man and a woman. ${ }^{109}$ Subsequently, the California Supreme Court upheld the above amendment as constitutional and California same-sex couples wishing to marry sued the California Governor and Attorney General in federal court alleging that the California amendment violated the federal Due Process clause and Equal Protection clause. The California executive officials named as defendants in the suit (who were charged with implementation and enforcement of state laws) refused to defend the lawsuit though they enforced the challenged law within the state. Under these circumstances, the proponents of Proposition 8 were allowed to intervene to defend the attacked law. Both the federal trial court and appeals court found the California law unconstitutional, and the trial court issued an injunction prohibiting state officials from enforcing the ban against marrying same-sex couples. ${ }^{110}$

While the appeal was pending before the USSCt, the situation in California was quite awkward. Several thousand same-sex marriages had been performed within the state during the interval between the 2008 California Supreme Court decision and the referendum on Proposition 8. This left matters unsettled not only among heterosexual and homosexual couples wishing to marry, but also among some of the latter who were already legally married within the state and others who might henceforth be prohibited from doing likewise. Finally, even those who had managed to obtain a same-sex marriage during the short period when California offered that alternative were facing a great uncertainty. Indeed, if the USSCt reversed the lower federal courts decisions, would the existing same-sex married couples be treated differently than their heterosexual counterparts? Would the former not be able to avail themselves of future benefits readily available to the latter?

\footnotetext{
108570 U.S. 133 S Ct 2652 (2013).

109 Ibid., 2659.

110 Ibid., 2660-63.
} 
A definitive USSCt decision on the merits would have resolved these uncertainties or at least stabilized expectations and allowed for greater harmonization throughout the US. The USSCt refused to address the merits of the case, however, on the grounds that the proponents of Proposition 8 did not have a legally sufficient adversarial stance to meet the 'case or controversy' requirement. Did the USSCt engage in sound jurisprudence or did it buckle under out of political concerns? From a practical standpoint, the USSCt made the decision of the federal trial court overturning California's ban on same-sex marriage final as it barred any appeal by the Proposition 8 proponents. Consistent with this, the trial court decision became de facto the final word for the State of California. Hence, while staying away from the merits, the USSCt in effect enshrined same-sex marriage as a constitutional right in California and thus rendered moot the uncertainties and concerns listed above.

One might conclude that the result in Hollingsworth amounted to a brilliant display of judicial craftsmanship with fortunate political side effects were it not for the USSCt's decision the same day in United States v Windsor. ${ }^{111}$ Windsor was a challenge against DOMA's prohibition against federal benefits available to opposite sex married individuals being also made available to their same-sex counterparts in a state that had legalized same-sex marriage. The Obama administration in Windsor took the same position as had the California Governor's administration in Hollingsworth: it enforced DOMA, but refused to defend its constitutionality in court. ${ }^{112}$ Unlike in Hollingsworth, a different line up of five justices held that the unwilling executive branch could be properly replaced for 'case or controversy' purposes by a (legislative branch) group made up of members of the US House of Representatives. Accordingly, the lower federal courts' holding that the challenged DOMA provision was unconstitutional was upheld on the merits by the USSCt. Interestingly, the USSCt Chief Justice who wrote the Court's opinion in Hollingsworth dissented in Windsor, but three justices joined the majority in both cases. ${ }^{113}$

DOMA defined marriage for all federal purposes to be exclusively between a man and a woman, thus in fact excluding lawfully married same-sex couples from the benefits provided by more than 1000 federal laws. ${ }^{114}$ In Windsor, the plaintiff had become the heir of her deceased same-sex spouse with whom she had resided in New York, a state where

\footnotetext{
111570 U.S. _, 133 S Ct 2675 (2013).

112 Ibid., 2683-4.

113 These were justices Breyer, Ginsburg and Kagan.

114 Windsor (n 111) 2694-5.
} 
same-sex marriage is lawful. Federal tax law does not impose any tax on any property left to one's surviving spouse. In the case of heterosexual marriage, state law determines whether a couple is lawfully married and therefore whether the federal tax exemption is applicable. In the case of Ms Windsor, however, whereas New York recognized her marriage as valid under its laws, DOMA deprived her of any exemption and she had to pay over $\$ 360000$ in estate taxes for which she sought a refund. ${ }^{115}$

On the merits, the USSCt held, based on well-settled, federalism-based jurisprudence, that since it is up to the states to determine the criteria for lawful marriages within their own boundaries, DOMA's recognition of some valid New York marriages to the exclusion of others was in violation of federal constitutional liberty and equality rights. ${ }^{116}$ Thus, in Windsor, as it had in Hollingsworth, the USSCt avoided addressing the question of whether the federal constitution should be understood as protecting a right to same-sex marriage. Beyond that, and although the circumstances and posture of the two cases are different, the upshot is that the USSCt silence on the merits in Hollingsworth results in the federal district (trial) court in that case having had the thus far final word to the effect that at least as far as California is concerned, the federal constitution guarantees a right to same-sex marriage that overrides that state's prohibition of the latter under its laws - much like nearly a half a century earlier the USSCt invalidated on similar grounds Virginia's ban on interracial marriage. ${ }^{117}$ In sharp contrast, in Windsor, the USSCt deferred to state's law on marriage and invalidated a federal law based on a combination of federalism and federal liberty and equality grounds. All this left the question of the constitutional status of same-sex marriage in a jurisprudential limbo, as it now turns out, for a two-year period.

Same-sex marriage, like abortion, is part of the culture wars that have long divided the US polity. Remarkably, the USSCt has been as cautious in the context of the former as it has been (perhaps unwittingly) intrepid in that of the latter. There is, however, one dramatic difference between the two. Opposition to same-sex marriage has greatly shrunk in the nearly two decades since DOMA was enacted. ${ }^{118}$ The split over abortion, on the other hand, seems to have remained fairly steady, both in terms of

\footnotetext{
115 Ibid., 2683.

116 Ibid., 2695.

117 See Loving v Virginia 388 US 1 (1967).

118 See, for example, Gallup Poll, 'Americans Favor Rights for Gays, Lesbians to Inherit, Adopt' (17 December 2012) <http://www.gallup.com/poll/ 159272/americans-favor-rights-gays-lesbians-inherit-adopt.aspx.> accessed 31 March 2015.
} 
numbers and of vehemence in the four decades since Roe $\mathrm{v}$ Wade. ${ }^{119} \mathrm{In}$ spite of this important difference, as the above discussion of the 2013 cases clearly indicates, it is difficult to disentangle the politics from the genuine constitutional issues involved and from the need to achieve a uniform judicial resolution of the latter. The two 2013 cases also plainly demonstrate that for all the USSCt did to avoid deciding the constitutional status of same-sex marriage, it in effect did so only in part thus accelerating the inevitable, now enshrined in the bitterly divided decision announced in Obergefell.

\subsection{CONCLUSION}

Constitutional review of fundamental rights in the US proves to be a complex and unique mix that weaves together different kinds of politics and conceptions of rights that can be regarded as rising above politics either in some Lockean pre- or extra-political sense or else in that they ought be cast ideally as rising above existing political divisions. As the ultimate constitutional adjudicator, the USSCt is exceptional and operates in a sui generis way that sets it apart from constitutional courts and other highest courts in most other civil law and common law jurisdictions. Moreover, the exceptionalism in question results from a confluence of factors that include: constitutional architecture; a legal tradition framed by an apparently seamless mutual adaptation between common law methodology and a written constitution; a strong constitutional identity that tends to transform most major contentious political issues into constitutional ones; a particularly strong ideological commitment to interpreting fundamental rights as nearly exclusively negative rights; and a very special institutional positioning of the USSCt that has developed over time and that now provides it with a privileged vantage point in terms of checks and balances and of the interplay between rule of law and politics.

As the above discussion regarding the USSCt highlights, one can maintain consistently a theoretical distinction between ordinary politics, judicial politics and constitutional jurisprudence based on an ideologically coherent conception of fundamental rights. Indeed, the USSCt's two 2013 same-sex marriage cases provide a vivid example of a conjunction between ordinary politics and judicial politics: the former made manifest by the concerted avoidance of a decision on the merits;

\footnotetext{
119 Roe v Wade (n 58).
} 
and the latter, by the concentration on the intricacies of the "case or controversy' constraints. Ironically, to the extent that Bush v Gore figures as a purely political outlier, it highlights how other cases, politically divisive though they may end up being - such as Roe v Wade or Citizens United - do contain a separable jurisprudential dimension steeped in a distinct conception of fundamental rights. The main problem from the standpoint of the USSCt's legitimacy as the ultimate constitutional adjudicator stems from practical difficulties in sorting out what ought to emerge as theoretically distinct in a large number of cases. Moreover, these practical difficulties do not only result from conflation of ordinary politics, judicial politics and constitutional jurisprudence. But also, these difficulties are to a significant extent the product of divisions within each of these domains. Transforming politically divisive issues into constitutional ones does not, in most cases, purge these of the ordinary political passions with which they have become identified. At the same time, judges are often divided over judicial politics and, given the clashes between restrictive and expansive interpretations of fundamental rights, over the proper meaning and scope of constitutionally enshrined fundamental rights. Under these circumstances, fluctuations in the perceived legitimacy of the USSCt adjudication depends on the interrelation between a complex set of factors. Success seems most likely when the various factors are better aligned or when the constitutional jurisprudence and rule of law dimensions of a decision appear to be more discernibly detached from politics.

By casting a comparatist's glance on US constitutional adjudication, one can place in sharper focus the many intricate and intertwined ways in which the latter is exceptional as well as the various paradoxes to which it gives rise. Switching directions, can a comparatist draw any lessons from the US case that may be useful in considering constitutional adjudication in other jurisdictions? At first, the answer would clearly seem to be in the negative. If we add up originalism, Lockean negative rights and the role of US federalism in fundamental rights adjudication, nothing comparable comes to mind in connection with other jurisdictions with developed practices of constitutional adjudication. On further reflection, however, and after attempting to set comparisons at the most appropriate levels of abstraction, the US example may well yield some worthy insights to comparativists examining constitutional adjudication in other jurisdictions. As it is impossible to properly support this latter claim within the scope of the present chapter, suffice it for now to mention a couple of possibilities that would warrant further exploration. The most obvious possibility, approached at a relatively high level of abstraction, concerns the nature and scope of fundamental rights to 
be safeguarded through adjudication in constitutional democracies. Abortion, assisted suicide and same-sex marriage, among others, raise similar issues and lead to similar debates in a large number of Western constitutional democracies. Moreover, in a large number of such democracies, there are controversies regarding whether, or to what extent, judges rather than legislators ought to have the last word. Even if institutional differences render comparison unfruitful at some levels of abstraction, the larger question of whether, for example, assisted suicide ought to be constitutionally guaranteed (based on some implied or explicit general privacy right) or left to democratic majorities poses similar challenges for judges in the US and in several other jurisdictions. A second possibility for fruitful comparison concerns the level of abstraction at which fundamental rights constitutional issues are, or ought to be, addressed by constitutional adjudicators. Institutionally, with its concrete ex post 'case or controversy' requirements, the US seems at one end of the constitutional adjudication spectrum where a civil law country, like France that once relied exclusively - and now in part - on abstract ex ante review would be at the other end of the same spectrum. A close comparison of US cases such as Roe v Wade and civil law court cases such as the GCC abortion decisions - is likely to reveal a great deal of congruence in how the constitutional adjudicator tackles the issues before her and how she handles the arguments and proposed resolutions concerning the contested constitutional question subject to her decision. In sum, US exceptionalism poses numerous challenges to the comparativist, but provided a proper balance is struck between similarities and differences, there seems to be ample room for US constitutional adjudication to prove illustrative and illuminating in the context of other jurisdictions. 